\title{
Dissidents and God-Talk in the Johannine Epistles
}

\section{Dunderberg, Ismo}

Vandenhoeck \& Ruprecht 2021

Dunderberg , I 2021, Dissidents and God-Talk in the Johannine Epistles . in U E Eisen \& H E Mader (eds), Talking God in Society : Multidisciplinary (Re)constructions of Ancient (Con)texts. Festschrift for Peter Lampe: Vol. 1: Theories and Applications . vol. 1 , Novum Testamentum et Orbis Antiquus / Studien zur Umwelt des Neuen Testaments , no. 120/1, Vandenhoeck \& Ruprecht , Göttingen , pp. 451-469 . https://doi.org/10.13109/9783666573170.451

http://hdl.handle.net/10138/323858

https://doi.org/10.13109/9783666573170.451

Downloaded from Helda, University of Helsinki institutional repository.

This is an electronic reprint of the original article.

This reprint may differ from the original in pagination and typographic detail.

Please cite the original version. 


\title{
Dissidents and God-Talk in the Johannine Epistles
}

\author{
Ismo Dunderberg
}

Peter Lampe announced two goals for his magisterial From Paul to Valentinus.

On the one hand, his study was focused on "the daily lives of the urban Roman Christians of the first two centuries, the realities of their social lives." On the other, he was engaged with the question of "where — if at all—interrelations between situation and theology can be discovered." In this way, Lampe sought to steer the discussion away from "superficial monocausalisms" that have been "produced by a one-sided social-historical interpretation or, occasionally, suggested by purely inner-theological, history-of-tradition analyses of texts."1

There has been no lack of proposals addressing "interrelations between situation and theology" in the study of the Johannine epistles. Yet, the question of how exactly theology and situation are interrelated is often inadequately addressed. In most analyses, theology determines situation. Theologies endorsed and rejected in the three Johannine epistles, especially in 1 John, are often regarded as defining the entire situation addressed in these texts. ${ }^{2}$

I seek to argue here for a more nuanced approach toward the "interrelations between situation and theology" in the study of the Johannine epistles. For one

\footnotetext{
${ }^{1}$ Lampe (2003), 2.

${ }^{2}$ See, e.g., Wengst (1976), 9: "I sought to offer ... as precise as possible an understanding of the situation to which the First John is written. This situation is above all defined by the opposition attacked in the epistle." Wengst finds "the definitive point of difference" between the author of 1 John and his opponents "in christology" (15).
} 
thing, we should not too readily impose a theological disagreement on the conflict between Diotrephes and the author of 3 John. There is enough evidence to suggest that the conflict had a "doctrinal" aspect, yet not in the sense of "doctrine" as "theological truth", but only in the weaker sense that the author and Diotrephes had different opinions. There is no clear evidence that they disagreed on God, Christ or other divine beings.

In the latter part of this essay, I explore how the author of 1 John uses Godtalk to construct a shared identity with the group he is writing to. I use as my point of departure recent studies in social psychology about leaders as "entrepreneurs of identity," which emphasize the active role that leaders play in forging social identities in and for their respective groups. My discussion will be focused on how the author of 1 John employs the notion of divine begetting for this effect and how his usage of it can be better understood in light of Philo, who also frequently reflected on this issue. ${ }^{3}$

\section{Overdoing Theology}

The three Johannine epistles are regularly explained as the result of theological controversies that broke the Johannine "community" asunder. This approach takes for granted that the group of addressees to whom the Johannine epistles were

\footnotetext{
${ }^{3}$ I wish to acknowledge here my debt to Dr. Sami Yli-Karjanmaa, who generously shared with me his expertise on Philo's views about divine birth and begetting.
} 
written was engaged in the same controversy and equally passionate about theology as the authors of these texts. This line of thought has also led to an endless guesswork about the opponents' viewpoints, which are allegedly quoted or referred to in these epistles. Opposing positions have customarily been detected in the claims that the author of 1 John rebuts (e.g., "if we say that we do not have sin," 1:8; "if we say that we have not sinned," $1: 10),{ }^{4}$ as well as statements that point to a discrepancy between what is said and what is done ("if we say that we have fellowship with him, and yet walk in darkness," 1:6; “one who says 'I've known him,' and yet does not follow his commandments," 2:4; “one who claims to be in light, and yet hates the brother," 2:9).

The assumption that the author is quoting his opponents' slogans has resulted in scholarly portrayals of the latter as considering themselves spiritually superior to others and, accordingly, showing little interest in the well-being of their fellow Christians (cf. 1 John 3:17, which is often read as a polemic against the author's "spiritualized" opponents). The link between this picture and the one painted in hostile sources of the second-century Valentinian Christians, whose claims to spiritual insight allegedly made them both arrogant and morally indifferent, has not gone unnoticed among scholars of the Johannine epistles. ${ }^{5}$ Though this point is clearly documented only rarely, I presume it is this similarity between the scholarly construct of the opponents of 1 John and the heresiological

\footnotetext{
${ }^{4}$ See, e.g., Brown (2006 [1982]), 762-763; Dodd (1946), 18; Painter (2002), 90-91; Smalley (1991), xxvi; Trumbower (1992), 137.

${ }^{5}$ The portrayal of Valentinians in hostile sources written by early heresy hunters should not be taken as a given, of course, but critically qualified in light of and as an example of ancient vituperation; see Dunderberg (2008), esp. 134-158.
} 
construct of the Valentinians that underlies the usual opinion that the opponents of 1 John were either "Gnostics" or "proto-Gnostics" on their way to full-blown "Gnosticism."

In more recent scholarship, the opponent-centered interpretation of the Johannine epistles has become subject to critical scrutiny. ${ }^{6}$ For instance, Judith Lieu has maintained that statements about the discrepancy between words and action in 1 John do not have to be based on anything the opponents said. The author nowhere accuses the opponents of being guilty of that discrepancy (or any other moral errors). Rather, such formulations are the author's own way to drive home the point he wants to make. ${ }^{7}$ The opponents' doctrinal profile becomes even dimmer if we agree with Lieu that the disagreement between the author of 1 John and his opponents was not about the incarnation of Jesus. In 1 John 4:2, incarnation is mentioned but not given as the object of right confession, ${ }^{8}$ and it is not mentioned in other related passages where the author speaks about denying and confessing Jesus $(2: 22 ; 4: 3,15)$. In the latter, the author does not portray his opponents as believing in Jesus in a wrong way, but as not believing in Jesus at all. $^{9}$

\footnotetext{
${ }^{6}$ For a comprehensive review of scholarly theories about the opponents in 1 John, see Streett (2011).

${ }^{7}$ Lieu (2008), 10-12.

${ }^{8}$ See Lieu (2008), 166-167. Lieu points out that the formulation in 1 John 4:2 should not be understood as acknowledging "that Jesus Christ has come in the flesh"; the point is that "the true spirit acknowledges 'Jesus Christ having come in the flesh' or 'Jesus Christ as having come in the flesh." Hence, the focus is on belief in Jesus, not on belief in his incarnation.

${ }^{9}$ See Lieu (2008), 167: "if Jesus Christ is not known and confessed as the one who has come, then he is not known at all."
} 


\section{Community and Entrepreneurs of Identity}

The purported scenario that the author of 1 John was writing to a community split by theological controversy is more problematic than it may look at first blush. Stanley Stowers has recently pointed out how much intellectual baggage comes with the concept of "community" that is popular in early Christian studies. One key problem is that it creates the image of a group that is of a special kind-one "with a deep social and mental coherence, a commonality in mind and practice." 10 As Stowers delineates, the use of "community" carries the implication that all members of a group were equally committed to the convictions proclaimed in our sources. In reality, it is impossible for us to know how deeply committed to those beliefs individual members of groups of early followers of Jesus may have been. It cannot be taken for granted that all, or even most, members of any such group were actively engaged in controversies about right theology and practice. It is more likely that such controversies were waged by only a few experts in theology, possibly including visiting ones (cf. 2 Cor 11:4-5; Gal 2:4).

Nevertheless, the social impact of the authors of our sources should not be underestimated either. While we cannot infer from the texts that they wrote what their addressees believed, these experts on matters we consider religious - such as opinions about the divine and cults — were in a constant dialogue with their audiences, seeking to persuade them toward the right course of action and

\footnotetext{
${ }^{10}$ Stowers (2011), esp. 242.
} 
dissuade them from wrong ones. ${ }^{11}$ While it is possible that some early followers of Jesus were completely indifferent to why they belonged to a certain group, group membership usually matters and is subject to reflection by individuals and collectively.

The discussion about the social impact of the authors of our sources may benefit from the concept of "entrepreneurs of identity," which theorists of social identity theory have coined in their studies about leadership. ${ }^{12}$ This idea notes that leaders are actively at work in crafting a "sense of us" for the groups they belong to. This does not have to mean that all members equally share or actively reflect on the leader's vision of the group identity. Nevertheless, it would also be a mistake to assume that people are indifferent about the groups they belong to. Membership matters to, and is subject to reflection by, group members: "social identities are immensely important to individual group members. They give us a sense of place in the world: who we are, what we should do, and how we relate to others." ${ }^{13}$ Such issues matter, since group membership involves "a process of selfstereotyping: that is, people ascertain the terms of the group definition ... and then seek to conform those norms." ${ }^{14}$

And yet, the "sense of us" that is of pivotal importance for the group does not simply evolve; it must be actively created. Hence, there is a demand for entrepreneurs of identity "to work to create and maintain a coherent sense of 'we'

\footnotetext{
${ }^{11}$ For an account of religious experts in the Roman world that is both comprehensive and compelling, see Wendt (2016).

${ }^{12}$ For a precursor to this approach in New Testament studies, see Shkul (2009).

${ }^{13}$ Haslam, Reicher \& Platow (2011), 144.

${ }^{14}$ Haslam, Reicher \& Platow (2011), 143.
} 
and 'us' and also to define what 'us' means (and does not mean) for followers."15 The "sense of us" within a group is, thus, always a constructed identity. Such constructions of identity come from leaders who actively forge the social identity in ways that best serve the goals they want to achieve with and through their respective groups.

Theorists of identity entrepreneurship further point out that there is a “dialectic relationship between (a) leadership constrained by existing social identities and (b) leadership as creative of social identities." ${ }^{16}$ Since their means of constructing group identity are constantly under critical scrutiny by their followers, leaders must be able to strike a delicate balance between "cultural knowledge and rhetorical skill." ${ }^{17}$ A successful leader has the knack for using the shared pool of cultural knowledge ("tradition") in a creative manner: "great leaders ... don't just repeat traditional stories of identity. They innovate. They draw on less well-known strands of group culture. They weave familiar strands into novel patterns.... Their genius is to make the new out of the elements of the old and thereby to present revolution as tradition." 18

\section{Identity Entrepreneurship in 1 John}

\footnotetext{
${ }^{15}$ Steffens et al. (2014), 1004.

${ }^{16}$ Haslam \& Reicher (2007), 127.

${ }^{17}$ Reicher, Haslam \& Hopkins (2005), 561.

${ }^{18}$ Haslam, Reicher \& Platow (2011), 149.
} 
Identity entrepreneurship is well attested in the Johannine epistles, especially in 1 John. Its self-designated purpose is to effect fellowship between the author and his addressees (1:3). Accordingly, the entire text functions as an attempt to forge a "sense of us" to bring together the author and the addressees. While the author distinguishes between the group of eyewitnesses of Jesus (to which he belongs) and the addressees_-"us" and "you" $(1: 3,5)$, respectively—he also constantly designates the addressees as being part of "us" and strictly differentiates them from other people.

One important aspect of the author's way of forging the "sense of us" is his construction of shared tradition, designated as the original teaching, which has

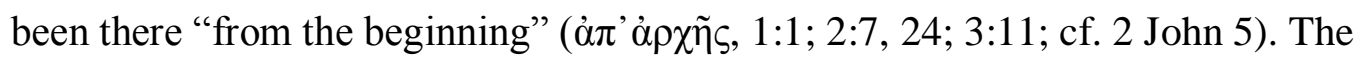
author's claim to the original teaching is so strong that it seemingly overrides the fact that his text is both situational and argumentative. While he is clearly addressing what he regards (or constructs) as a new situation — that is, the problem of false teachers- - he presents everything that he says in the text as the original teaching, which has always been there: "what was from the beginning, what we have heard, what we have seen with our eyes, what we saw and our hands touched upon ... we proclaim also to you that you would have fellowship with us" (1:1-3).

The author's unexpected affirmation that the addressees do not need anyone teaching them, due to the divine anointing they have received (2:27), serves the same purpose. Given that the author himself has taught—and in this text teaches - the addressees, the lesson here must be that the addressees need no other teaching than what they have received — and probably will continue to receivefrom the author. 
Moreover, the author crafts the "sense of us" in terms of loyalty to ("abiding within") "our" tradition: "As for you, what you heard from the beginning should abide within you. If what you heard from the beginning abides in you, also you will abide in the Father and the Son" (2:24). The author's construction of shared tradition turns any competing teaching into a deviation from what is (and has always been) common to "us." In effect, this strategy places anyone propagating or approving any other teaching outside of "us."

One obvious example of identity entrepreneurship based on "less wellknown strands of culture" is the resurgence of apocalyptic imagery in 1 John. It is commonly noted that apocalyptic rhetoric figures much more prominently in 1 John than in John's gospel (e.g., awareness of "the last hour" and the appearance of "antichrists," 2:18; the expectation of Christ's imminent second coming, 2:28). ${ }^{19}$ This suggests that the author of 1 John was capable of "activating" this less well-known — and yet probably not completely unknown — aspect of shared tradition in crafting a social identity for his addressees. Such activation of the apocalyptic register not only lends a sense of urgency to the author's teaching, it also entails a strict polarity between "us" (as "the children of God") and "them" (as "the children of the Devil"), which serves the purpose of demarcation that the author wants to achieve between true believers and those attaching themselves to wrong teachers.

${ }^{19}$ See, e.g., Hakola (2015), 75-76; Strecker (1986), 41. 


\section{Absence of God-talk in 3 John}

One striking feature in the three Johannine epistles is that while much is said about God in 1 John, the theme is conspicuously absent in 3 John. Academic interpreters of 3 John have often sought to explain the lack of theology in 3 John by attributing theological and/or ecclesial positions to Diotrephes, whose policy of exclusion is bitterly protested against in the few lines the author of 3 John writes to an otherwise unknown Gaius.

Given how little information about Diotrephes is offered by the author of 3 John, the common narrative of placing Diotrephes on the axis between orthodoxy and heresy seems bewildering. Was he the leader of a heretical faction, thus bearing witness to the success of heresy over orthodoxy in early Christianity (see Bauer) $?^{20}$ Or was he instead an orthodox bishop exercising church discipline over and against the Johannine author of 3 John, who exemplified a less formal and Spirit-inspired vision of leadership and was inclined to gnostic views (see Käsemann) $?^{21}$ Or was the author of 3 John in the end waging a campaign on people who were precisely like that — namely, those who "represented gnosticizing or spiritual tendencies contrary to the presbyter's apocalyptic teaching about Christ" (see Strecker) ${ }^{22}$

${ }^{20}$ Bauer (1971), 93-94.

${ }^{21}$ Käsemann (1951), 292-311. Vouga $(1990,11)$ also detects in 1 John a "gnostic selfunderstanding" that "characterizes the (author's) fellowship with his addressees."

${ }^{22}$ Strecker (1996), 263. 
What makes these squarely opposed theories about Diotrephes possible is the complete lack of evidence in 3 John about his views. The letter clearly shows that its author was unhappy with Diotrephes' policy of not extending a welcome to the author's couriers. In addition, the conflict was no doubt a real one. This much can be inferred from the fact that the author was forced to admit defeat in the situation. The text indicates that Diotrephes had won the upper hand in the assembly and had been able to mobilize other people against the author's messengers (3 John 9-10). Ending up on the losing side was certainly a source of shame for the author, who sought in the epistle to restore his honor and authority $^{23}$ — and also secure the loyalty of the addressee Gaius, whom the author portrays as one of his spiritual children (3 John 4).

Moreover, there was a doctrinal dimension to the debate between the author and Diotrephes. Although we are left in uncertainty as regards to what it concerned precisely, there must have been some reason why Diotrephes declined to offer hospitality to the author's couriers. It seems that Diotrephes' action was in one way or another related to the author's teachings. The epistle suggests that Diotrephes' unfriendly actions toward the author's envoys ensued from "something" the author had written "to the assembly" (3 John 9). Given that Diotrephes began to urge other people to adopt the same policy of exclusion as he did toward the author's couriers (3 John 10), he must have had serious qualms about "something" the author had written.

\footnotetext{
${ }^{23}$ See Malina (1986), 187.
} 
This, however, is all we know about the debate between the author and Diotrephes. The author neither attributes any particular ecclesial task to

Diotrephes nor details what in his previous text had irked that person so much that he acted against the author's envoys.

While there is no way of knowing more about the disagreement, the debate was not necessarily about doctrine in the sense of "theological truth." In principle, it may have been on that kind of issue. We know of instructions offered to early Christ groups that they should only welcome visitors who demonstrated full compliance with the received teaching in those groups, and we know from 2 John that this policy was also commended among Johannine followers of Jesus. ${ }^{24}$ The problem with this explanation, however, is that the author of 3 John neither refers to any such tests of true faith nor announces any doctrinal disagreement with Diotrephes. He only accuses Diotrephes of moral errors, such as gossiping and lust for power.

Another possibility is that Diotrephes was concerned about some other aspects than theology (in the sense of "God-talk") in the author's teaching. John Kloppenborg has recently pointed out that leaders of ancient associations could be concerned with anything that risked factionalism in their groups. Kloppenborg

\footnotetext{
24 "If someone comes to you and does not subscribe to this teaching ( $\delta$ เ $\delta \alpha \chi$ ), do not take this person to your home nor greet him" (2 John 10). "And so, welcome anyone who comes and

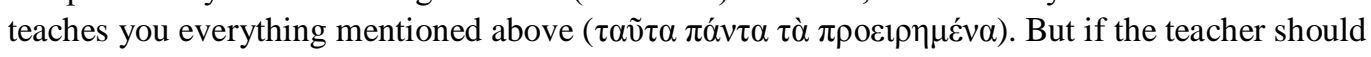

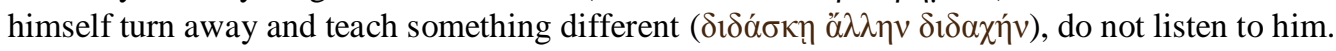
But if his teaching brings righteousness and the knowledge of the Lord, then welcome him as the Lord" (Didache 11:1-2, transl. Ehrman). Neither text details how an "entrance exam" of this kind could have been conducted in practice. Unless members of the respective groups had checklists at hand, which they could resort to upon a visitor's arrival, one would assume that the visitor's wrong views would arise and be dealt with gradually rather than immediately when they came.
} 
compellingly suggests that the Johannine love commandment, which was confined to insiders and thus entailed a strict division between "us" and "them" (cf. John 15:12; 1 John 2:10; 3:11; 4:7), could have easily been regarded in this way. ${ }^{25}$ While Kloppenborg uses this perspective to explain the references to the expulsion from the synagogue in John's gospel (John 9:22, 34; 12:42; 16:2), it could also very well apply to the situation addressed in 3 John. Diotrephes may have been concerned about factionalism within his group. For this reason, he may have been more willing than the author of 3 John to accept the idea of corpus mixtum, in which the distinction between true and false believers was less sharply pronounced than the author of 3 John would have preferred. ${ }^{26}$ We do not have any definite information about Diotrephes' thoughts or motives, but this explanation has the advantage that it offers a solution that is firmly rooted in the reality of ancient voluntary organizations and the challenges that their leaders faced. ${ }^{27}$ In any case, Diotrephes' policy of exclusion was probably not based upon any clearcut theological disagreements with the author of 3 John (since the author does not mention any). This makes more likely the possibility that Diotrephes intervened

\footnotetext{
${ }^{25}$ Kloppenborg (2011).

${ }^{26}$ For one parallel to this attitude, see Matthew 13:24-29, where it is affirmed that the division between the two sets of believers only becomes visible in the final judgement.

${ }^{27}$ In another study, Kloppenborg delineates the ways the associations mimicked the administrative structures and policies of the city. Here he points out that Shepherd of Hermas (Sim. 1.1-3.6) provides us with an account referring to the expulsion from the city; see Kloppenborg (2017), 49-53. It is notable that the language of expulsion used in 3 John coincides

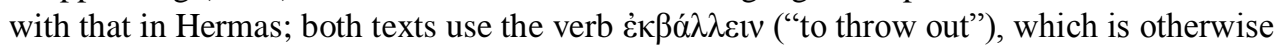
unusual in New Testament texts. This may suggest that the author of 3 John describes the expulsion of his people in terms that were customarily used in Greco-Roman associations. The

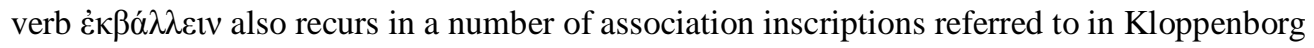
(2011); see 11: IG II2 1396.40-44 and IG II2 1339.136-46, with the latter describing an officer's duty "to expel those who fight".
} 
because of the potential or real consequences of that author's teachings on the social life of the assembly.

\section{Divine Origin and Knowledge about God in 1 John}

While God-talk is entirely absent in $3 \mathrm{John}$, it looms large in $1 \mathrm{John}$. The term "God" ( $\theta \varepsilon$ ós) occurs in 1 John more frequently than in any other New Testament text. ${ }^{28}$ This epistle appears "theocentric" in comparison to John's gospel, which is more "christocentric": some designations connected with Jesus in John's gospel are used for God in 1 John. ${ }^{29}$

Forging the "sense of us" characterizes the God-talk in 1 John. Most affirmations about God in this text are linked with ones about "us." Above all, language of origins, family, and kinship figures prominently in the author's Godtalk, and these features are constantly intermingled with each other. The author portrays the audience as belonging to a divine family: "we are called the children of God, and that is what we are ... we are now beloved children of God" (3:1). The author affirms in a variety of ways that, as children of God, the addressees have their origin in God. Not only are they "from God" $(4: 4,6 ; 5: 18)$, but they are

\footnotetext{
${ }^{28}$ On the basis of the statistics provided by Accordance XII software, the word $\theta \varepsilon$ co has 28.93 hits per 1000 words in 1 John, while John's gospel only features 5.30 hits. The only other texts in the New Testament featuring more than 20 hits per 1000 words for $\theta \varepsilon$ có are Romans (21.50), 1 Thessalonians (24.24), 2 Thessalonians (21.79), and 1 Peter (23.17).

${ }^{29}$ See Hakola (2015), 75. One prominent example is Jesus as "light" (John 1:4-5, 9; 3:19; $8: 12 ; 9: 5 ; 12: 35-36,46)$ and God as "light" (1 John 1:5).
} 
also "begotten from God" $(3: 9 ; 4: 7 ; 5: 18)$ — just like Jesus "is begotten from God" (5:1). The metaphor of conception finds a very concrete aspect in the affirmation that God's seed $(\sigma \pi \varepsilon \dot{\varepsilon} \rho \alpha)$ resides in those "begotten from God" (3:9). The notion of the audience's kinship with God is amplified with the polarity drawn between "the children of God" and "the children of the Devil" (3:8). The latter are also designated as those being "not from God" $(3: 8 ; 4: 6)$ - just like the erroneous spirits not confessing Jesus "are not from God" $(4: 2) .{ }^{30}$

The divine origin of God's children entails knowledge about God (4:7). There is no clear distinction between "being from God" and "knowing God," since both designations can used interchangeably: "We are from God. One who knows God listens to us. One who is not from God does not listen to us" (4:6). While here one's divine origin and knowledge about God are bluntly identified with the acceptance of "our" teaching (either that of the author or that of the ideal community), the author also links these features to the right course of action, which is always expected to be shown toward those belonging to "us" (as tokens of love among the "brothers," 4:7-8; cf. 3:16-18; 4:11).

While the rhetoric of divine origin in 1 John seems fixed and deterministic, it is accompanied with other kinds of statements that allow fluidity. The transition from death to life that the author presents as shared tradition implies a less fixed

\footnotetext{
${ }^{30}$ Trumbower (1992), 138, affirms that in 1 John, the expressions "birth from God," "being from God," and "children of God" "no longer denote fixed and determinative categories in 1 John, but rather they are used to designate the change which took place when the believer entered the community." I would insist rather that these are indeed determinative and fixed categories - just like the opposite category of "those from the Devil." The language of fixed origins, however, does not exclude the fluidity implied by the possibility of transition from one group to another (from "death" to "life").
} 
idea of identity than that of divine begetting: "we know (oǐ $\delta \alpha \mu \varepsilon v)$ that we have passed from death to life because we love the brothers" (3:14). The author also envisions a future transformation of "us," which entails assimilation to God: "We are now beloved children of God, and yet it has not been revealed what becomes of us. We know that when he will appear, we will become just like him since we will see him as he truly is" (3:2).

As Rudolf Bultmann rightly recognized in his New Testament Theology, the Johannine discourse implies that the believer's origins are changed: "He can exchange his Whence, his origin, his essence.” The same goes also for the unbelievers (cf. John 8:23, 44). One's origins are thus determined by one's "decision between faith and un-faith." 31

The notion that one's origins are negotiable rather than fixed seems less surprising in light of Denise Buell's insightful study on ethnic reasoning in antiquity and among early Christians. Buell points out that fixity and fluidity went hand in hand in ancient reasoning about "us":

Although ethnicity and race are concepts frequently constructed through appeals to fixity (essences, including lineages and "nature"), they can also be constructed through appeals to malleability. That is, definitions of ethnoracial membership can foreground "achievement" (not merely "ascription"). If seeking to portray ethnicity as attainable, one might stress the centrality of common purpose, common language or education (paideia), way of life, or religious practices. Even claims of fixity are subject to fluidity in practice. ... Ancient definitions of ethnicity do not necessarily occupy one of the extreme ends of the ascribed/achieved (or fixed/fluid) spectrum I have mapped. Frequently, they exhibit some combination of appeal to both fixity and fluidity... ${ }^{32}$

\footnotetext{
${ }^{31}$ Bultmann (1955), 2.25.

${ }^{32}$ Buell (2005), 41.
} 
Buell maintains that "genealogical appeals are important for ethnic reasoning ... because they offer a central way of communicating a sense of ethnic/racial 'fixity,' essence, and continuity." She further points out how "followers of Christ regularly defined themselves as descendants of key figures such as Abraham (Paul, Justin, Pseudo-Clementine Recognitions), Seth (Gospel of the Egyptians, Apocryphon of John), Norea (Hypostasis of the Archons) as well as Jesus (Aristides' Apology, Justin's Dialogue with Trypho). In such texts, one's futurespecifically one's access to salvation-depends on membership in the correct descent group." ${ }^{33}$ The Johannine self-definition of "us" as the offspring of God operates in the same manner. It simultaneously emphasizes the importance of one's membership in the correct group and the "achieved" aspect inherent in that status, since it entails the expectation of right behavior being shown toward other members of the group.

\section{Philo and 1 John on Divine Begetting}

Bultmann correctly saw that in Johannine usage, the expressions "to be from" and "to be born from" "serve to characterize men and their conduct ... and denote the individual's essence which asserts itself in all his speaking and doing..."34 However, Bultmann's assumption that the language of divine birth in Johannine

\footnotetext{
${ }^{33}$ Buell (2005), 75-76.

${ }^{34}$ Bultmann (1955), 2.20.
} 
texts presupposes a full-blown Gnostic myth, stripped of its cosmic aspects, seems unnecessary. ${ }^{35}$ The variety of ways in which Philo speaks of assimilation to God and divine begetting offers a closer point of comparison to the language of divine kinship used in 1 John. Admittedly, the goal of Philo's reflections about these issues is very different from that of 1 John. Philo constantly develops viewpoints pertaining to the hierarchy and inner divisions of the soul, whereas "soul" is not mentioned in 1 John at all. In this sense, Philo stands much closer to the philosophical tradition than the author of 1 John. Yet, what is common to both authors is the intimate connection that they draw between ethical reasoning and the notion of divine birth.

The notion of divine begetting (or divine birth) is rare in the Hebrew Bible. ${ }^{36}$ In Deuteronomy 32:18, the entire nation of Israel is addressed as one that "forgot the God who gave birth to you." In Psalm 2:7, the divine adoption of a new king is expressed in terms of begetting: "You are my son; today I have begotten you." Followers of Christ attached this passage to Jesus (Hebr 1:5; 5:5; Acts 13:33; Luke 3:22 [D]). The notion of divine adoption inherent in the messianic interpretation of Psalm 2:7 is one viable option for how the author of 1 John may have conceived of the exchange of one's origins, for although he never speaks of rebirth (cf. John 3), the transition from death to life he posits for true believers suggests that he understands divine begetting in terms of a new, spiritual birth. It

${ }^{35}$ Bultmann (1955), 2.20, opined that the expressions in the Johannine texts "to be from" and "to be born from" God "have lost the cosmological sense that they have in the Gnostic myth and denote to the individual's essence which asserts itself in all his speaking and doing and determines the Whither of his way."

${ }^{36}$ See Büchsel (1964), 668-669. 
seems feasible that the new birth from God could also be expressed in terms of one's new origins that stem from God.

Unlike in the Hebrew Bible, the language of divine begetting looms large in Philo's works. While he constantly designates God as the begetter of all things, ${ }^{37}$ most of his reflections about divine begetting are focused on the mind (voṽ $)$ and the virtuous life of human beings. Philo designates the mind as a virgin begotten by God "when it dwells with virtuous reasoning ... and impregnates it with thoughts of highest excellence" (Spec. 2:30). In principle, the entirety of humankind is God's kin because of the faculty of logical reasoning bestowed on all humans (Opif. 74, 146). Nevertheless, for Philo, kinship with God most often expresses potentiality for an intimate relationship with the Creator. Only some people fully realize this potentiality. Divine kinship becomes real through consideration of "spiritual and divine natures," which also brings about the right course of action (Opif. 144).

Two items in Philo's on this point bring him close to the viewpoints expounded in 1 John. First, Philo teaches that kinship with God is only possible with the help of the divine spirit. It is the divine spirit, which "had flowed" into one "in full current," that enables a person to enjoy the bliss brought about by "being of near kin to the Ruler" (Opif. 144). Just like the author of 1 John, Philo also reckons with the existence of an opposite spirit, characterized by its "tyranny rife with lawlessness ( $\pi \alpha \rho \alpha v o \mu$ í $\alpha)$ and cruelty" (Her. 60). The second point that

\footnotetext{
${ }^{37}$ See, e.g., Mut. 29, 63; Dec. 1:209; Spec. 1:209, 329; 2:198, 261; 3:189; Somn. 2:178; Aet. 1; Praem. 46; Virt. QG 2:34.
} 
Philo and the author of 1 John have in common is the Platonic ideal of one's assimilation to God (Plato, Theaetetus 176; cf. 1 John 3:2: "We will become like him"). ${ }^{38}$ In Philo, this goal is more clearly linked with the right course of action than it is in 1 John, for the spirit-possessed person aspires "in all his words and actions to please the Father and King, following him step by step in the highways cut out by virtues since only for souls who regard it as their goal to be fully

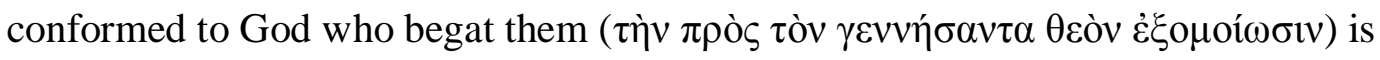
it lawful to draw nigh to him" (Opif. 144).

Despite his insistence that God has begotten everything, including all of humankind, Philo also designates some specific groups of people as Godbegotten. The aspect of potentiality linked with divine begetting may explain the tension between the universal and the particular interpretations in Philo: only a few people realize their true nature as God-begotten, even though this nature resides in all humans. ${ }^{39}$ However that may be, Philo distinguishes one group as “God-begotten," calling them "people of God" ( $\theta \varepsilon \circ \tilde{v}$... ö $v \theta \rho \omega \pi \mathrm{or})$. These persons are "priests and prophets," who have completely detached themselves from the world. They have "refused to accept membership of the world" and "have risen wholly above the sphere of sense-perception" (Gig. 61)..$^{40}$ These Godbegotten persons are distinct from, and superior to, two other categories of people,

${ }^{38}$ For Philo's appropriation of this notion in Plato, see Yli-Karjanmaa (2015), 86-87.

${ }^{39}$ See Spec. 1:332. Philo calls ungodly people "the children of a harlot" because such children do not know their father, just as ungodly people are ignorant of their true Father. This presupposes that these people are also God's children but do not know it.

${ }^{40}$ For Philo, complete detachment from the world is also peculiar to the perfect mind: "the mind, which has been perfectly cleansed and purified, and which renounces all things pertaining to creation, is acquainted with the One, and knows but the One" (Plant. 64); see Yli-Karjanmaa (2015), 97. 
which are: (1) "the earth-born," yielding to "the pleasures of the body," and (2) "the heaven-born," who are "lovers of knowledge" (but, by implication, reluctant to completely cut their ties to the world as fully as the "people of God"?) (Gig. $60)$.

Although the language of divine begetting, here reserved only for one group, may sound fixed, the three categories are malleable in Philo. Philo interprets the change of Abram's name to Abraham (Gen. 17:5) as denoting his transition from the middle class ("man of heaven" and "lover of learning") to the superior class ("man of God"). The transition implies that it is possible to become "God-begotten"- that is, to receive a new origin — in the same way as presupposed in $1 \mathrm{John}$.

For Philo, the transition from "a man of heaven" into "a man of God" also entails perfection, since Abraham's entrance to the latter involves his becoming "blameless" in front of God (Gig. 62; cf. Gen. 17:1). The way Philo here emphasizes the virtuous lifestyle of those begotten by God, illustrated by the blameless Abraham, brings his teaching close to the affirmation in 1 John that those begotten from God "do not $\sin .$. and are not able to sin because they are begotten from God" (3:9; cf. 5:18). ${ }^{41}$ The attributes that Philo reserves for one special class of people (e.g., divine begetting, blamelessness) are thus used in 1 John for the entire in-group. In other words, the author of 1 John forges a social

\footnotetext{
${ }^{41}$ Philo also bears witness to the same tension as found in 1 John (cf. 1:8-10) between the possibility of sinless life and the affirmation that all humans sin; cf. Deus 76: "there is no person who self-sustained has run the course of life from birth to death without stumbling, but in every case his footsteps have stopped through errors, some voluntary, some involuntary."
} 
identity by imposing on this group an ideal self, based upon features that in Philo are only ascribed to a chosen few.

As was pointed out above, divine begetting and knowledge of God go hand in hand in 1 John. For Philo, "knowledge of the One" is one of the features distinguishing the special class of "the sons of God"; Philo thinks the affirmation of divine begetting in Deut. 34:18 refers to these people in the know.

Unsurprisingly for Philo, knowledge of God becomes visible in virtuous behavior: "They hold moral beauty to be the only good, and become warriors against pleasure" (Conf. 145).

The author of 1 John does not connect divine begetting as clearly as Philo to the struggle against emotions, but he also insists that "nothing in the world - the flesh's desire, the eyes' desire and arrogance brought about wealth—is from God" (2:16). Thus, the author of 1 John shares with Philo both the ideal of detachment from the world ("do not love the world nor anything in the world," 2:15) and the ensuing notion that this detachment involves freedom from harmful emotions.

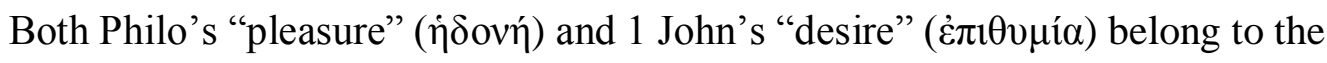
four "basic" emotions in Stoic analysis, and they seem to agree with one another (and with the Stoics) that the tyranny of emotions can be combatted — at least by some ideal persons (Philo) or by “us” (1 John).

The metaphor of sowing appears frequently in connection with Philo's references to divine begetting. God as the perfect Father sows and begets happiness in human souls (Leg. All. 3:219), while one's propensity toward God involves reception of "the seed of understanding" ( $\tau \grave{\alpha} \varphi \rho \circ \eta \eta \sigma \varepsilon ́ \omega \varsigma . . \sigma \pi \varepsilon ́ \rho \mu \alpha \tau \alpha$, Post. 135). God's activity as the sower and begetter of "honorable births" ( $\tau \grave{\alpha}$ 
$\dot{\alpha} \sigma \tau \varepsilon \tilde{\imath} \alpha \gamma \varepsilon v v \eta \dot{ } \mu \alpha \tau \alpha)$ lays the basis for, and results in, "fulfilment of the law"; furthermore, it makes humans "march in whatever direction God leads the way" (Migr. 143-43.) God's sowing thus emphasizes humans' potential ability to engage in right action.

In Philo, "seed" stands for potentiality toward something: "And if some seed of recovery should appear in him ... it should be cherished as we fan an ember with every care. For we may hope that the germ may grow and spread, and that thus humans may lead a better and more stable life" (Sacr. 123). Philo uses the language of a divine seed to emphasize that the source of virtue lies outside humans: "Virtue receives the divine seed from the Creator" (Cher. 46). Hence, souls prone to virtue can only "accept the seeds of impregnation that are showered on them from outside, and revere the Giver, and thus by honoring God they repel the love of self" (Congr. 130). One would be unable to live a virtuous life if God did not "send down the seeds from heaven to cause her [Sarah] to be pregnant, and if she would not give birth to Isaac, that is, happiness in its totality..." Happiness, however, does not follow from merely possessing virtue that God has planted in human beings. The divine seed provides humans with the ability to engage in a virtuous life, but this ability needs to be put into practice. What brings about happiness is the "exercise ( $\chi \rho \tilde{\eta} \sigma ı \varsigma)$ and enjoyment of virtue" (Det. 60). Divine impregnation fills one with "seeds of virtue ( $\tau \tilde{\omega} v \dot{\alpha} \rho \varepsilon \tau \tilde{\eta} \varsigma \sigma \pi \varepsilon \rho \mu \alpha \dot{\tau} \omega \nu)$," 
while the ensuing pregnancy results in the birth of "good actions ( $\alpha \alpha \lambda \grave{\alpha} \varsigma \pi \rho \alpha ́ \xi \varepsilon 1 \varsigma)$ " (Deus 137). ${ }^{42}$

Hence, in Philo, the notions of the divine seed and impregnation bring together fixed (acquired) and fluid (achieved) aspects of one's kinship with God. This notion combines the idea of God as the only source of virtue with one's responsibility to put this innate, God-given ability into practice by living a virtuous life. The author of 1 John does not dwell on the concept of the divine seed in any such detail. In light of Philo's reflections, however, it seems possible to assume that the divine seed in 1 John 3:9 denotes one's ability to follow the right course of action. This would explain the affirmation that sinlessness results from one's possession of the divine seed. At this point, the author of 1 John seems to negate the aspect of potentiality inherent in Philo's understanding of the divine seed, since he boldly contends that it is impossible for those begotten by God to $\sin .{ }^{43}$ This radical affirmation is balanced with other statements, however; he notes that all addressed group members sin and must confess those sins (1:8-10), and he describes sinlessness as a goal rather than a fact $(2: 1-2)$.

Philo links the language of sowing with the masculine form of reproduction. Even Wisdom, who is "God's daughter," "is not only masculine but also father,

\footnotetext{
${ }^{42}$ See Draper (2017), 7: “God, as the unbegotten begetter, sows his divine seed ( $\tau \dot{\alpha} \theta \varepsilon \tilde{\alpha} \alpha$ $\sigma \pi \varepsilon \dot{\varepsilon} \mu \alpha \tau \alpha)$ in human beings not to bring forth children for himself since he needs nothing ( $\dot{\eta} \delta \dot{\varepsilon}$

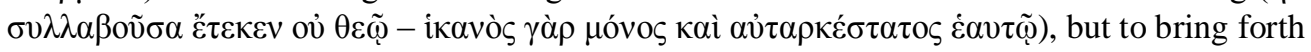
virtue to human beings by the divine life within them."

${ }^{43}$ van der Watt (1999), 496, explains this notion as emerging from ancient family ethics: “'Being born of God' is the reason why a child of God cannot sin. Identity - nothing like freedom of choice or a particular situation - basically determines the child's actions, both positively and negatively." Accordingly, he links the claims about "us" still commiting sins with the problem of "disobedience in practice" that was often addressed in ancient philosophy as part of family issues (ibid. 497-497).
} 
sowing and begetting in souls aptness to learn, discipline, knowledge, sound

sense, good and laudable actions" (Fug. 50). Here again the author of 1 John may

be close to Philo. Turid Karlsen Seim has pointed out that the Johannine language

of reproduction is thoroughly masculine; it does not involve any female

contribution: ${ }^{44}$

In the Gospel of John ... there is no female principle involved in the divine begetting and birth-giving. The mother does not matter because matter is what she provides. The only begotten God/Son who is in the кó $\lambda \pi$ o $\varsigma$ of the Father (John 1:18) bears the children of God, in whom the $\sigma \pi \varepsilon \dot{\varepsilon} \rho \alpha$, that is, the $\pi v \varepsilon \tilde{v} \mu \alpha$ of God, abides. They are begotten as well as born not of bloods, not of the will of flesh or of the will of man, but of God, that is of Father and Son-one in their will and purpose and both with the exclusive quality of having life in themselves.

The cooperation of two males in divine reproduction that John's gospel presupposes is not really reflected upon in 1 John. Yet, the fact that the author of this text speaks of God's seed demonstrates that the author thinks of divine

\footnotetext{
${ }^{44}$ Seim (2005), 375. While Seim maintains that John's gospel presupposes the Aristotelic epigenesis but removes from it the female element, Rothschild (2010) suggests that John's theory of reproduction stands closer to ancient theories about parthenogenesis (usually linked with plants). Rothchild concludes that "the Fourth Gospel may shift parthenogenesis from an explanation of Jesus' biological birth (attested in Matthew and Luke) to an explanation of Jesus' divine birth." In addition, Rothschild argues that the way the divine birth of the believer is described in John 3:8 (stemming from pneuma as Spirit, compared to pneuma as wind) also recalls the notion of parthenogenesis: "to be born from above ... is to allow the mixed male and female components of the "soul" (or human aspect susceptible to truth) to be carried like a seed on the wind to a natural landing place in which it can generate and grow" (137). This reading could be supported with references to Philo, who describes the divine begetting as opposed to the human one and in terms of virginity: "For the union of human beings that is made for the procreation of children turns virgins into women. But when God begins to consort with the soul, he makes what was before a woman into a virgin again" (Cher. 50). Philo also uses a vegetative analogy to describe how the divine seed within human beings needs to be nourished. He explains the name of Seth as denoting "watering" (Post. 10, 124, 170) and infers from this that the figure of Seth allegorically refers to the way in which "the word of God waters the virtues; for the word of God is the source and spring of noble conduct" (Post. 127). (This explanation seems erroneous since "Seth" in Hebrew means "reproduction" or "replacement"; cf. LVTL s.v.)
} 
reproduction in terms of begetting rather than in terms of giving birth. Philo articulates this point in greater detail. In his view, divine birth is not only something extraordinary but it also lacks female contribution. For him, the Sabbath day was "motherless, exempt from female parentage," and divine Wisdom, albeit being female, acts toward humans as the Father and begetter of the soul's right inclination. For Philo, Sarah, who due to old age was no longer able to contribute the female element to her pregnancy, illustrates "the virtue ... who is the motherless beginning ( $\dot{\alpha} \mu \eta \dot{\tau} \omega \rho \dot{\alpha} \rho \chi \eta ்)$, begotten of the Father alone, who is God over all things" (Her. 62).

\section{Conclusion}

This essay developed a few viewpoints in response to Peter Lampe's endeavor to study "interrelations between situation and theology." To determine such interrelations can be quite complicated both theoretically — as Stanley Stowers' critical review of the concept "community" as unified by faith and practice demonstrates - and exegetically. There is a strong tendency in our field to assume that all members of "communities of faith" were constantly preoccupied with issues pertaining to right doctrine and praxis. I am more inclined to the view that such issues were probably subject to debate first and foremost among religious experts who had sufficient knowledge and interest (and time) to wage battles of right interpretation. Such people, however, were of pivotal importance to their 
respective groups as entrepreneurs of identity, who forged the "sense of us" for those groups. These specialists provided members of their groups with narratives of what brought their "us" together. The specialists' constructions of social identity mattered (and continue to matter), since membership matters to group members. I also suggested that debates between early Christian specialists did not have to be about "theology" in the strict sense; they could also be about (potential or real) social consequences of one teaching or another.

In the latter part of this essay, I explored the notions of divine begetting and divine seed, which the author of 1 John used to craft the "sense of us" for his audience. These notions are especially well suited for that purpose, since they simultaneously affirm the indicative (one's divine origin) and the imperative (the ensuing ethical obligation to love other members of the community). ${ }^{45}$ As the comparison to Philo showed, the link in 1 John between one's divine begetting and the right course of action is by no means unique.

The comparison to Philo also raises another issue, which is the social standing of the author of 1 John. In my estimation, the analogies referred to above are close enough to suggest that the two authors shared some common ground. And yet there are differences. The author of 1 John was clearly less "philosophical" than Philo; most of the key terms and issues in Philo—-such as

\footnotetext{
${ }^{45}$ This conclusion brings my reading close to van der Watt's insightful study on ethics based on birth, family and kinship in 1 John; see van der Watt (2014), 207: "The effect of relating birth to behavior, with all expectations that went along with it (i.e., behave according to your social position of birth, obey your father, allow your identity determined by the group, etc.) is that a person lives within a framework of expected behavior based on his birth. The child is under an obligation to behave according to the will of the one from whom he or she was born."
} 
"virtue", the inner structure of the soul, and moral progress - are absent in 1 John. What is more, as is often noted, the author of 1 John rarely, if ever, develops any advanced chains of argumentation. At the same time, the fact remains that both authors shared an interest in divine begetting, which plays a marginal role in the Hebrew Bible, and developed views about right behavior based on this notion. In my opinion, the affinity is close enough to suggest that the author of $1 \mathrm{John}$ had some advanced knowledge about Hellenistic (Jewish?) philosophy, which he resorted to in crafting the "sense of us" for the addressees of his text. This being the case would justify our seeing in the author of 1 John a precursor to early Christian intellectuals. A glimpse of Platonic theology in the epistle-the expectation of "our" assimilation to God (3:2) — points in the same direction, as does the polemic against desire in 1 John 2:16.

\section{Bibliography}

Bauer, Walter., Orthodoxy and Heresy in Earliest Christianity (transl. Philadelphia Seminar on Christian Origins; Philadelphia, PA: Fortress, 1971 [German original: 1934; the English translation is based the second German edition from 1964]).

Brown, Raymond E., The Epistles of John: A New Translation with Introduction and Commentary (AncB 30; New Haven, CT: Yale University Press 2006 [1982]).

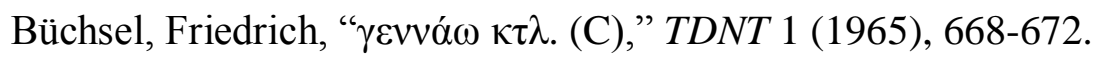

Buell, Denise Kimber, Why This New Race: Ethnic Reasoning in Early Christianity (New York, NY: Columbia University Press, 2005).

Bultmann, Rudolf, Theology of the New Testament (2 vols; transl. Kendrick Grobel; New York: Charles Scribner's Sons, 1955). 
Dodd, C.H., The Johannine Epistles (London: Houlder and Stoughton, 1946).

Draper, Jonathan, "Not by human seed but born from above to becomechildren of God: Johannine metaphor of the family or ancient science?" In die Skriflig 51/3 (2017), a2201 [https://doi.org/10.4102/ids.v51i3.2201]

Dunderberg, Ismo, Beyond Gnosticism: Myth, Lifestyle, and Society in the School of Valentinus (New York: Columbia University Press, 2008).

Hakola, Raimo, Reconsidering Johannine Christianity: A Social Identity Approach (New York, NY: Routledge, 2015).

Haslam, Alexander S. \& Stephen Reicher, "Identity Entrepreneurship and the Consequences of Identity Failure: The Dynamics of Leadership in the BBC Prison Study," Social Psychology Quarterly 70/2 (2007), 125-147.

Haslam, S. Alexander \& Stephen D. Reicher \& Michael J. Platow, The new psychology of leadership: identity, influence, and power (New York : Psychology Press, 2011).

Käsemann, Ernst, "Ketzer und Zeuge: Zum johanneischen Verfasserproblem," ZTK 48 (1951), 292-311.

Kloppenborg, John S., "Disaffiliation in associations and the $\dot{\alpha} \pi 0 \sigma v v \alpha \gamma \omega \gamma o$ of John," HTS Teologiese Studies/Theological Studies 67/1 (2011), Art. \#962.

Kloppenborg, John S. "Associations, Christ groups, and their Place in the Polis.," ZNW 108 (2017), 1-56.

Lampe, Peter, From Paul to Valentinus: Christians at Rome in the First Two Centuries (transl. Michael Steinhauser;ed. Marshall D. Johnson; Minneapolis, MN: Fortress, 2003).

Lieu, Judith, I, II \& III John: A Commentary (The New Testament Library; Louisville, KY: Westminster John Knox Press, 2008).

Malina, Bruce J., "The Received View and What It Cannot Do: III John and Hospitality," Semeia 35 (1986), 171-194.

Painter, John, 1, 2, and 3 John (Sacra Pagina Series 18; Collegeville, MN: The Liturgical Press, 2002).

Reicher Stephen \& S. Alexander Haslam \& Nick Hopkins, "Social identity and the dynamics of leadership: Leaders and followers as collaborative agents in the transformation of social reality," The Leadership Quarterly 16 (2005), 547-568. 
Rothschild, Clare K. "Embryology, Plant Biology, and Divine Generation in the Fourth Gospel," in Women and Gender in Ancient Religions: Interdisciplinary Approaches (ed. Stephen P. Ahearne-Kroll, \& Paul A. Holloway \& James A. Kelhoffer,; WUNT 263 (; Tübingen: Mohr Siebeck, 2010), 125-51.

Seim, Turid Karlsen, "Descent and Divine Paternity in the Gospel of John: Does the Mother Matter," NTS 51 (2005): 361-375.

Shkul, Minna., Reading Ephesians: Exploring Social Entrepreneurship in the Text (LNTS 408; London: T\&T Clark, 2009).

Smalley, Stephen S., 1, 2, 3 John (WBC 51; Milton Keynes: Word Publishing, 1991).

Steffens, Niklas K. et alii, "Leadership as social identity management: Introducing the Identity Leadership Inventory (ILI) to assess and validate a four-dimensional model," The Leadership Quarterly 25 (2014): 1001-1024.

Stowers, Stanley, “The Concept of 'Community' and the History of Early Christianity," MTSR 23 (2011), 238-256.

Strecker, Georg, "Die Anfänge der johanneischen Schule,” NTS 32 (1986), 31-47.

Strecker, Georg The Johannine Epistles: A Commentary on 1, 2, and 3 John (transl. Linda M. Mahoney; Hermeneia; Minneapolis, MN, 1996).

Streett, Daniel R., They went out from us: The Identity of the Opponents in First John (BZNW 177; Berlin, 2011).

Trumbower, Jeffrey A., Born from Above: The Anthropology of the Gospel of John (HUT 29; Tübingen: Mohr Siebeck, 1992).

van der Watt, Jan, "Ethics in First John: A Literary and Socioscientific Perspective," CBQ 61 (1999), 491-511.

van der Watt, Jan, "On Ethics in 1 John," in Communities in Dispute: Current Scholarship on the Johannine Ethics (ed. R. Alan Culpepper \& Paul N. Anderson; Atlanta, GA: Society of Biblical Literature, 2014), 199-222.

Vouga, François, Die Johannesbriefe (HNT 15/III; Tübingen: Mohr Siebeck, 1990).

Wendt, Heidi, At the Temple Gates: The Religion of Freelance Experts in the Roman Empire (Oxford: Oxford University Press, 2016).

Wengst, Klaus, Häresie und Orthodoxie im Spiegel des ersten Johannesbriefes (Güterloh: Gütersloher Verlagshaus, 1976). 
Yli-Karjanmaa, Sami, Reincarnation in Philo of Alexandria (Studia Philonica Monographs 7; Atlanta: SBL Press, 2015). 
